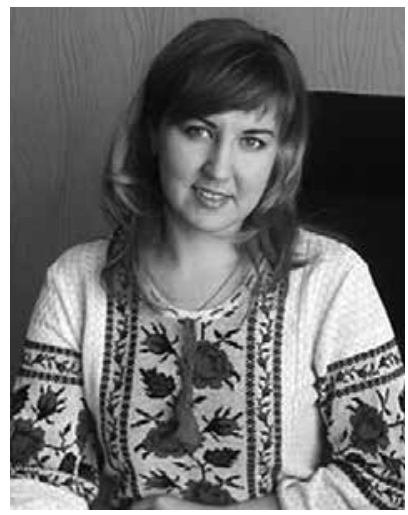

Харітонова М. В.,

аспірант кафедри кримінального процесу

Одеського державного університету

внутрішніх справ

ORCID ID: 0000-0002-2877-7247

\title{
Науковий керівник:
}

Г. К. Тетерятник, кандидат юридичних наук, дочент, завідувач кафедри кримінального прочесу

Одеського державного університету внутрішніх справ

DOI: https://doi.org/10.17721/2413-5372.2019.3/239-248

УДК 343.13(470)(075.8)

\section{ІМУНІТЕТ СВІДКІВ ЯК ЕЛЕМЕНТ ПРИНЦИПУ ОХОРОНИ ПРАВ І СВОБОД ЛЮДИНИ ТА ГРОМАДЯНИНА У КРИМІНАЛЬНОМУ СУДОЧИНСТВІ}

Анотація. В умовах фрормування правової держави одним з найбільших проявів демократизації правоохоронної діяльності в Україні є законодавче забезпечення прав людини, створення гарантій прав і законних інтересів особистості. У зв'язку з цим особливого значення набуває правове забезпечення процесуального статусу учасників кримінального судочинства. Крім того, важливим завданням кримінально-процесуальної науки є виявлення та усунення прогалин у правовому регулюванні кримінально-процесуальних відносин. У зв'язку з цим на даний час активно проводяться дослідження з виявлення проблем правової регламентації в даній галузі права і на цій основі виробляються рекомендації щодо їх усунення.

Як відомо, кожен учасник кримінального судочинства має закріплений в нормах Кримінального процесуального кодексу України власний правовий статус. Процесуальному статусу потерпілого, підозрюваного, обвинуваченого законодавець і вчені-процесуалісти приділяють багато уваги, в тому числі питань забезпечення їх прав і законних інтересів. Процесуальний статус свідка в кримінальному судочинстві вимагає, на наш погляд, додаткового дослідження, в тому числі через призму забезпечення прав і законних інтересів даної особи при проведенні досудового розслідування і судового розгляду у кримінальному провадженні. Дослідження проблем теорії і практики реалізації імунітету свідків $є$ актуальним, оскільки різні аспекти імунітету свідків викликають суперечки як серед теоретиків, так і серед практичних працівників. Звісно ж, що перш за все саме для свідків важлива наявність додаткових можливостей захисту з боку держави.

Мета статmі полягає у розгляді актуальних проблем, що виникають у зв'язку реформуванням кримінального процесуального законодавства, яке створило певні труднощі у правозастосовній практиці, в тому числі й при реалізації норм, що визначають інститут 
імунітету свідків. Зокрема, це пояснюється суперечливими, часом невдало сформульованими положеннями самого законодавства, не завжди послідовної реалізацією завдань судової реформи. Крім того, у статті підіймається проблема класифрікації імунітету свідків. Розглядаються різні точки зору авторів на поняття та складові імунітету свідків. Розкриваються дискусійні питання класифрікації імунітету свідків та наводиться його поділ на види за категоріями та обсягом показань, що надаються свідками.

Результатом дослідження є надання обгрунтованих пропозицій щодо вдосконалення правової регламентації інституту імунітету свідків у кримінальному процесі. Імунітет свідка - це сукупність правил, які звільняють певні групи свідків від обов'язку давати показання у кримінальному провадженні, а також звільняють від обов'язку свідка свідчити проти себе самого. У зв'язку з цим імунітет для свідка підрозділяється на два види імперативний (абсолютний, безумовний) і диспозитивний (відносний, умовний).

Ключові слова: імунітет для свідка; класифрікація імунітету свідків; кримінальне провадження, свідок, імунітет свідка, право на захист обсяг і предмет показань; види імунітету.

П остановка проблеми. Забезпечення можливості реалізації демократії в сучасному розумінні стосується усіх сфер держави та суспільства, в тому числі, і кримінального судочинства, до якого, залучається широке коло учасників. Відповідно, державного захисту прав та свобод потребують всі без винятку учасники кримінального провадження не залежно від процесуального статусу, позиції, зацікавленості у результатах вирішення кримінального провадження.

Під забезпеченням прав людини розуміється «діяльність органів державної влади та місцевого самоврядування, громадських об'єднань і посадових осіб щодо створення сприятливих умов (гарантій) - для правомірною і неухильної реалізації та правового захисту». ${ }^{1}$

У науковій літературі, нормативних правових актах стосовно прав людини використовуються різні терміни - «забезпечення», «охорона», «захист». На нашу думку, всі зазначені поняття мають «деяку лексичну i смислову близькість, складаючи основу конституційних прав людини і громадянина. У той же час, визнаючи особу, іiі права і свободи як основного об'єкта, вони якісно відрізняються між собою за своєю метою і змістом, оскільки являють собою різні аспекти здійснення прав людини і громадянина» ${ }^{2}$. Так, Н. І. Матузов вважає, і ми підтримуємо таку точку зору, що «права особи охороняються постійно, а захищаються тільки тоді, коли порушуються» ${ }^{3}$. Охорона має прояв, насамперед, у реалізації заходів, спрямованих на попередження порушень прав людини. Зауважимо, що, на нашу думку, більш широким поняттям, яке включає в себе і їх охорону (коли права ще не порушені), і їх захист (коли реалізація прав ускладнена), і їх відновлення (коли права порушені) є забезпечення прав і законних інтересів особи.

У зв'язку 3 викладеним важливим завданням кримінально-процесуальної науки є виявлення і усунення прогалин у правовому регулюванні кримінально-процесуальних відносин. Що, у свою чергу, потребує проведення дослідження 3 виявлення проблем правової регламентації в даній галузі права та вироблення рекомендацій щодо їх усунення.

Аналіз останніх досліджень і публікацій. Окремі аспекти пов'язані з процесуальним статусом свідка висвітлювались в роботах Ю.П. Аленіна, І.В. Гловюк, Ю. М. Грошевого, В.Т. Нора, М. А. Погорецького, В.В. Рожнової, С.Р. Тагієва, О.Ю. Татарова, Л.Д. Удалової, М.Є. Шумила та ін. Безпосереднім об’єктом дослідження інститут імунітета

\footnotetext{
А Стремоухов, Правовая защита человека (СПбГУП 2007) 65

2 А Ендольцева, Ю Ендольцева, 'Обеспечение прав и законных интересов свидетеля при производстве по уголовному делу'(2018) 4 Вестник экономической безопасности 129-134.

3 П Фадеев, 'Проблемы фрормирования понятий уголовно-процессуального права и их влияние на правоприменительную практику'(2017) 6 Законы России: опыт, анализ, практика 104-108.
} 
свідка став у наукових роботах Г.Ф. Горського, Л.М. Карнеєвої, Л.Д. Кокорєва, М.С. Строговича. Після закріплення основ імунітету свідка в КПК України з'явилися дисертаційні роботи О.В. Белькової, Р. В. Баранніка, С. Г. Волкотруба. Цією проблемою займались М.М. Михеєнко, В.П. Шибіко, С.М. Стахівський та інші вчені. Проте вказані дослідження лише фрагментарно торкаються проблемних питань імунітету свідків, не забезпечують в повному обсязі розкриття інституту імунітету свідка в кримінальному провадженні та його класифікацію, що, у свою чергу, не вирішує всіх існуючих проблем правозастосування, які, на жаль, носять системний характер.

Метою статті $є$ розгляд актуальних проблем, що виникають у зв'язку реформуванням кримінального процесуального законодавства, яке створило певні труднощі у правозастосовчій практиці, в тому числі й при реалізації норм, що передбачають особливі порядки кримінального провадження щодо реалізації інституту імунітету свідків. Розгляд різних точок зору авторів на поняття та складові імунітету свідків. Розкрити дискусійні питання класифікації імунітету свідків та навести його поділ на види за категоріями та обсягом показань, що надаються свідками.

Виклад основного матеріалу та результатів дослідження. Будь-яке кримінальне провадження неможливо уявити без участі свідка. Це пов'язано з тим, що свідок - незамінне джерело відомостей, які мають значення для встановлення наявності чи відсутності обставин, що підлягають доказуванню у кримінальному провадженні, передбачених ст. 91 КПК України, а також інших обставин які мають значення для правильного вирішення кримінального провадження. Показання свідків $є$ найпоширенішим видом доказів.

У ст. 65 КПК України надано поняття даного учасника кримінального процесу, а також закріплюються його права і обов'язки. Відповідно до ч. 1 ст. 65 КПК України свідком є фізична особа, якій відомі або можуть бути відомі обставини, що підлягають доказуванню під час кримінального провадження, і яка викликана для давання показань. Слід зауважити, що більш правильним було б говорити про те, що свідкові відомі не самі обставини, що мають значення для кримінального провадження, а відомості про ці обставини. По-друге, зовсім не обов'язково, щоб свідок був викликаний для надання показань, адже він може самостійно прийти в орган досудового слідства, його показання можуть бути отримані за місцем його знаходження.

Буквальне тлумачення даної статті дозволяє зробити висновок про те, що свідок, на відміну від таких учасників кримінального судочинства, як потерпілий, підозрюваний з'являється вже на початковій стадії кримінального провадження, тому що наділення особи процесуальним статусом свідка не пов'язане $з$ винесенням слідчим будь-якого процесуального акта (постанови, повідомлення тощо). Разом 3 тим, законодавець в п. 25 ст. 3 КПК України безпосередньо називає свідка та його адвоката, учасниками кримінального провадження і ми припускаємо, що свідок мається на увазі законодавцем як одна $з$ осіб, «які беруть участь у кримінальному провадженні».

У ч. 3 ст. 66 КПК України передбачено насамперед право осіб, які беруть участь у кримінальному провадженні, не свідчити проти самого себе, свого чоловіка (своєї дружини) та інших близьких родичів, коло яких визначено п. 1 ч. 1 ст. 3 КПК України.

Кримінально-процесуальний кодекс України у ст. 18 формулює зміст імунітету свідків, як «жодна особа не може бути примушена давати пояснення, показання, які можуть стати підставою для підозри, обвинувачення у вчиненні іiі близькими родичами чи членами iii сім'ї кримінального правопорушення».

Право свідка відмовитися свідчити проти самого себе, свого чоловіка (своєї дружини) та інших близьких родичів, коло яких визначено п. 1 ч. 1 ст. 3 КПК 
України, а також встановлення заборони на допит за певними обставинами окремих категорій свідків. Разом 3 тим, сутність імунітету свідків набагато ширше сформульованих в КПК України положень. Дане правове явище можна розглядати як додаткову гарантію учасника кримінального процесу, що надається законодавством України у зв'язку з особливою процесуальної роллю свідка, як виняток $з$ принципу рівноправності громадян, як спосіб підвищити рівень безпеки свідка як учасника кримінального судочинства, як засіб боротьби $з$ недоліками інквізиційного процесу, як наріжний камінь змагального кримінального судочинства.

В даний час в чинному законодавстві, а також в науці кримінально-процесуального права склалися різні підходи до поняття «імунітет для свідка». Під імунітетом свідків розуміється інститут кримінально-процесуального та інших процесуальних галузей права, що закріплює заборону на примусовий допит певних категорій осіб з метою захисту охоронюваних Конституцією цінностей. ${ }^{1}$ Але, як зазначає О.В. Ткаля, - українська юридична наука чіткого визначення правового імунітету як правової категорії не дає $\epsilon^{2}$.

Воно логічно випливає з норм права, які регламентують зміст цього інституту. Як зазначає С.В. Тасаков імунітет для свідка являє собою інститут кримінального судочинства, спрямований на реалізацію захисту прав і свобод людини. ${ }^{3}$ Інститут імунітету свідків демонструє баланс між суспільним інтересом встановлення істини у кримінальному провадженні і потребою у збереженні приватних інтересів особистості. ${ }^{4}$
В. Нор пропонує називати інститут не «імунітетом свідків», а «частковим імунітетом свідків», 3 огляду на те, що йдеться не про повний імунітет свідків, а про частковий, усічений. «Особи, які звільняються від відповідальності за відмову давати показання, не мають таких характеристик діяльності, якими володіють посадові особи, тобто такі якості, як важливість, значущість, незалежність. Тому вони мають право мати лише свого роду усічений, частковий імунітет, що звільняє їх від відповідальності за відмову давати показання як свідків. Він призначений для забезпечення дотримання морально-етичних норм». Слід зауважити, що законодавство України не передбачає повного (абсолютного) імунітету від кримінальної відповідальності для будь-якої категорії громадян. Вищезгадана назва була б виправданою за умови, якби у кримінальному судочинстві існував повний імунітет свідків, а відтак, виникла потреба їх розрізняти. ${ }^{5}$

С.М. Стахівський визначає імунітет свідків як «...безумовне чи обмежене звільнення деяких груп громадян від обов'язку давати показання, серед яких можна виділити осіб: 1) яких заборонено допитувати як свідків; 2) які мають право відмовитися від дачі показань; 3) які можуть відмовитися відповідати на окремі запитання. Разом з тим про імунітет свідка допустимо вести мову лише тоді, коли особа може бути свідком, але має право відмовитись від дачі показань» ${ }^{6}$. На думку Т. М. Москалькової, імунітет свідків це «...сукупність правил, які звільняють деякі категорії свідків і потерпілих від передбаченого законом обов'язку дава-

\footnotetext{
1 В Волкотруб, 'Актуальні питання імунітету свідків в кримінальному судочинстві'(2003) 3-4 (7-8) Вісник Хмельницького інституту регіонального управління та права: наук. часопис 245

2 О Ткаля, Класифікація правових імунітетів (2012) 20 (Т. 1) Науковий вісник Ужгородського національного університету 48

3 С Тасаков, 'Нравственное содержание положений уголовного и уголовно-процессуального закона о свидетельском иммунитете'(2009) 1 Бизнес в законе 226-228.

4 М Веселов, Т Заремба, В Олешицька, 'Інститут імунітету свідка в кримінально-процесуальному праві'(2017) 3 Юридичний науковий електронний журнал 124-128

5 В Нор, 'Свідок у кримінальному процесі України: коло осіб, предмет показань та свідоцький імунітет 1 Радник: Український юридичний портал <http://radnuk.info/home/ > дата звернення. 1210.2019.

6 С Стахівський, ‘Показання свідка як джерело доказів у кримінальному процесі'(автореф. дис. .... канд.
} 
ти показання по справі, і також тих, що звільняють будь-якого допитуваного від обов'язку свідчити проти себе самого». ${ }^{1}$

Як вже зазначалось, КПК України визначає імунітет свідка як право відмовитися від дачі показань у певних законом випадках. Таке трактування можна було б віднести до числа спірних, оскільки термін «імунітет для свідка» має цілком інший зміст. Зарубіжна кримінально-процесуальна доктрина, з урахуванням досвіду, який практикується в США, тлумачить інститут імунітету свідків, як звільнення від кримінальної відповідальності і покарання осіб, на яких, при визначених у законі обставинах, може бути покладено обов'язок дати так звані самовикриваючі показання. ${ }^{2}$ Трактування імунітету свідків як можливості «відмовитися свідчити проти самого себе» спірна і з точки зору етимології слова «імунітет».

У системному взаємозв'язку необхідно розмежовувати правові поняття «імунітет», «недоторканність», «привілей», «пільга». Дані поняття, незважаючи на тісний взаємозв'язок, $є$ самостійними правовими категоріями, мають як загальні риси, так і відмінні ознаки, що не дозволяє вважати їх ідентичними. Імунітет - це особливі правові гарантії недоторканності, що забезпечують режим невтручання, якими наділяється особа $з$ огляду на особливі відносин між нею і суспільством, державою, іншими людьми. Імунітет залежить від соціального і професійного статусу особи, її правового положення в суспільстві, наділення особи особливим правовим статусом $з$ боку держави. Привілеї засновані на перевагах, виняткові права в сформованих правовідносинах.
Досвід міжнародного співробітництва в сфері кримінальної юстиції, успіх якого в певній мірі залежить від однакового сприйняття його учасниками відповідних термінів і понять, підказує доцільність зміни ставлення до того, що прийнято називати привілеями свідків. Ф.Г. Григор'єв зазначав, що залежно від умов реалізації привілеїв свідків, їх можна було б класифікувати на такі, які свідок має на підставі наданого йому права, i такі, які засновані на заборонах розголошення охоронюваних законом таємниць. Під привілеєм свідка слід розуміти право особи повністю або частково відмовитися від дачі показань у якості свідка у передбачених законом випадках ${ }^{3}$.

Не можуть бути допитані як свідки священнослужителі - про відомості, одержані ними на сповіді віруючих (п. 5 ч. 2 ст. 65 КПК України). У кримінально-процесуальному законі не дається визначення сповіді, про зміст якої не дозволено допитувати священнослужителя. Сповідь - це обряд покаяння в гріхах перед священиком і відпущення ним цих гріхів, відверте зізнання в чому-небудь, відверте і щире каяття в чому-небудь ${ }^{4}$.

Ст. 26 закону «Про друковані засоби масової інформації (пресу) в Україні» ${ }^{5}$ в переліку прав журналіста передбачено право на збереження таємниці авторства та джерел інформації і кореспондуючий йому обов'язок задовольняти прохання осіб, які надають інформацію, щодо ї авторства або збереження таємниці авторства, те ж саме міститься в статті 59 ЗУ «Про телебачення та радіомовлення», що телеорганізація зобов'язана зберігати у таємниці, на підставі документального підтвердження, відомості

\footnotetext{
юрид. наук К. УАВС, 1996) 17

1 П Москалькова, Этика уголовно-процессуального доказывания (стадия предварительного расследования) (Москва, Спартак 1996) 46

2 О Белькова, 'Теоретичні та практичні аспекти права свідка відмовитися свідчити відносно себе, членів сім'ї та близьких родичів'(2004) 2 Підприємництво, господарство і право 102-105.

3 Ф Григорьев, 'Процессуальное положение свидетеля в уголовном судопроизводстве'(дис. .... канд. юрид. наук. М. 2009) 11

4 Український тлумачний словник. Тезаурус. 250000 слів та словосполучень.2016250

5 Про друковані засоби масової інформації (пресу) в Україні: Закон України від 16.11.1992 р. № 2782-XII <https://zakon.rada.gov.ua/laws/show/2782-12 > дата звернення 10.04.2019
} 
про особу, яка передала інформацію або інші матеріали за умови нерозголошення іiі імені, тоді як Закони України «Про інформацію», «Про друковані засоби масової інформації (пресу) в Україні» одностайно наполягають на тому, що джерело інформації повинно бути розкрите за рішенням суду. Дана обставина дає підставу для постановки питання про внесення в КПК України доповнень 3 метою регламентації умов і порядку розкриття журналістської таємниці в ході досудового слідства та судового розгляду у кримінальному провадженні.

Дійсно, імунітет наділяє своїх власників єдиною, зате значною перевагою правовою недоторканністю. Імунітет надається не в особистих інтересах відповідних осіб, а з метою реалізації цілого комплексу конституційних прав людини і громадянина.

Є підстави провести класифікацію поняття імунітету свідків, як привілеїв особливих преференцій, які звільняють особу від дачі показань проти себе самого (привілей проти самозвинувачення), свого чоловіка (дружини) і близьких родичів (з огляду на родинні відносини) через можливість настання негативних правових наслідків, а також безпосередньо імунітету свідків - заборона допиту особи, на яку покладено обов'язок щодо нерозголошення певної категорії відомостей, з огляду на виконання ним громадських, державних, професійних та інших функцій.

Імунітет для свідка $\epsilon$ сукупністю трьох складових: привілеї від самозвинувачення; привілеї від дачі показань проти близьких родичів; імунітет професійних та інших функцій, що звільняє від дачі показань. ${ }^{1}$

Для правильного розуміння сутності інституту імунітету свідка особливе значення має його класифікація.

І.П. Корякін наводить наступну класифікацію імунітетів у кримінальному процесі: 1) за різновидом рішень, що приймаються; 2) за процесуальним положенням суб'єктів кримінального судочинства; 3) за взаємовідносинами, що регулюються імунітетом. У свою чергу, до першої групи належать такі: 1) імунітет від кримінального переслідування; 2) імунітет від надання свідчень; 3 ) імунітет від обшуку, виїмки, арешту майна, огляду, проникнення у житло або інше приміщення. До другої групи належать такі імунітети: 1) імунітет потерпілого; 2) імунітет свідка; 3) імунітет експерта; 4) імунітет цивільного позивача та відповідача; 5) імунітет приватного обвинувача. До третьої групи - імунітети, що регулюють правову та моральну конкуренцію. Під правовою конкуренцією, на думку автора слід розуміти наявність ситуації, за якої виникнення якого-небудь різновиду імунітету викликано наявністю в іншій галузі права норми, яка за своєю сутністю закликає до звільнення суб'єкта кримінального процесу від кримінальних процесуальних обов'язків. При цьому моральна конкуренція $€$ конкуренцією морально-етичних норм 3 нормами кримінального процесуального права, внаслідок якої пріоритет надається морально-етичним нормам та особа звільняється від кримінальних процесуальних обов'язків ${ }^{2}$

Проте, на нашу думку в даній класифікації втрачено межі лаконічності та конкретизованості позиції щодо систематизації імунітетів у кримінальному процесі.

Досліджуючи питання класифікації імунітетів у кримінальному процесі, $Ф$. А. Агаєв пропонує такі різновиди інституту імунітету: 1) дипломатичний; 2) імунітет осіб, які користуються міжнародним захистом; 3) депутатський імунітет; 4) посадовий імунітет суддів, посадових осіб правоохоронних та контролюючих органів; 5) імунітет свідка; 6) імунітет Президента, осіб прибулих 3-за кордону для участі у справі у якості

1 В Мельников, 'Институт свидетельского иммунитета в уголовном процессе'(2016) 3 Северо-Кавказский юридический вестник. <https://cyberleninka.ru/article/n/institut-svidetelskogo-immuniteta-v-ugolovnomprotsesse-rossii > дата звернення 10.10.2019.

2 И Корякин, 'Иммунитет в уголовном судопроизводстве' (дис. ... канд. юрид. наук:12.00.09. М.,2003) 65 
свідків, їх представників та експертів, які останній об'єднує під загальною назвою «інші імунітети» ${ }^{1}$

Розглядаючи питання класифікації імунітетів у кримінальному процесі В.І. Руднєв відокремлює такі різновиди імунітетів: 1) професійні (якими користуються президент, судді, прокурори, депутати); 2) особисті (якими можуть наділятись близькі родичі особи, які притягуються до кримінальної відповідальності); 3) змішані (якими можуть користуватись священики, адвокати, оскільки цим особам можуть стати відомими особистісні, потаємні відомості від громадян, що довірились їм). ${ }^{2}$

С.В. Лукошкіна пропонує їх поділ за двома системами враховуючи суб'єктну ознаку та об'єкти гарантування. Отже, за суб'єктною складовою автор пропонує таку класифікацію імунітетів у кримінальному процесі: 1) дипломатичний та консульський імунітет; 2) імунітет голови держави (імунітет президента, екс-президента та кандидати у президенти); 3) імунітет представників законодавчої гілки влади - парламентський імунітет; 4) імунітет посадових осіб судової гілки влади (судді всіх ланок судової системи, враховуючи присяжних та арбітражних засідателів); 5) посадові особи правоохоронних та контролюючих органів (голова Рахункової палати, його заступники та аудитори; прокурори, слідчі, члени виборчої комісії, комісії референдуму 3 правом вирішального голосу); 6) імунітет адвоката; 7) свідоцький імунітет.

За об'єктами гарантування науковець поділяє сфери впливу імунітету на: 1) особисту недоторканість; 2) недоторканість житлових, службових приміщень та приватних резиденцій, а також особистих та службових транспортних засобів; 3) привілеї зв'язку; 4) недоторканість майна, активів, приватної та службової переписки, архівів та інших документів ${ }^{3}$

Розглядаючи питання визначення класифікації імунітетів у кримінальному провадженні, слід звернути увагу на позицію О.В. Ткаля, яка дотримується позиції, що у кримінальному процесі правовий імунітет використовується у формі імунітету свідка, а також особливого порядку, викликаного здійсненням публічних функцій, застосування примусових заходів і проведення слідчих дій. ${ }^{4}$

Більш слушною є позиція С.Г. Волкотруба, який пропонує наступну класифікацію імунітетів у кримінальному провадженні: 1) імунітети посадових осіб, що виконують особливі за своєю вагою і значенням функції у державі та суспільстві; 2) імунітети, пов'язані з міжнародними відносинами; 3) імунітет свідків у кримінальному судочинстві. ${ }^{5}$ Слід погодитись з О.О. Обозною, що запропонована автором класифікація імунітетів $\epsilon$ досить вдалою для згрупування імунітетів у кримінальному процесі з суб'єктним складом. Отже, за суб' єктним складом імунітет поділяється на: 1) імунітет виборних та посадових осіб; 2) імунітет врегульований нормами міжнародного права; 3) імунітет свідка.

У свою чергу, до першої групи імунітетів доцільно віднести такі субінститути імунітету: а) імунітет глави держави; б) депутатський імунітет; в) імунітет інших посадових осіб. До імунітетів врегульованих нормами міжнародного права слід віднести дипломатичний, консульський імунітет, а також імунітет представників міжнародних організацій, місій тощо. ${ }^{6}$

\footnotetext{
Ф Агаев, 'Иммунитеты в российском уголовном процессе' (дис. ... канд. юрид. наук: 12.00.09. М., 1997) 64

2 В Руднев, 'Иммунитеты в уголовном судопроизводстве' (дис. ... канд. юрид. наук:12.00.09. М.,1997) 21.

В Руднев, 'Иммунитеты в уголовном судопроизводстве' (дис. ... канд. юрид. наук:12.00.09. М.,1997) 47.

4 О Ткаля, 'Класифікація правових імунітетів'(2012) 20 (Т. 1) Науковий вісник Ужгородського національного університету 82.

5 С Волкотруб, 'Імунітет і проблеми його захисту в кримінальному судочинстві' (дис. ... канд. юрид. наук: 12.00.09. Х., 2002) 33.

6 О Обозна, 'До питання класифікації імунітетів у кримінальному процесі України' (2017) 2 Європейські
} 
Більш переконливою нам видається думка вчених, які виділяють не два, а три види суб'єктів, що користуються імунітетом свідка: 1) абсолютний імунітет заборона допитувати як свідків; 2) відносний імунітет - можливість відмови від дачі показань; 3) імунітет осіб, які можуть відмовитися відповідати на окремі поставлені запитання ${ }^{1}$.

Імперативний (абсолютний, безумовний) імунітет сформульований як заборона допитувати деяких осіб в якості свідків. Його мають особи, які повинні зберігати в таємниці відомості, отримані ними під час виконання своїх професійних чи службових обов'язків. Абсолютним показанням свідків імунітетом наділені: 1) захисник, представник потерпілого, цивільного позивача, цивільного відповідача, юридичної особи, щодо якої здійснюється провадження, законний представник потерпілого, цивільного позивача у кримінальному провадженні; 2) адвокати; 3) нотаріуси; 4) медичні працівники та інші особи, яким у зв'язку 3 виконанням професійних або службових обов'язків стало відомо про хворобу, медичне обстеження, огляд та їх результати, інтимну і сімейну сторони життя особи; 5) священнослужителі; 6) журналісти; 7) судді та присяжні; 8) особи, які брали участь в укладенні та виконанні угоди про примирення в кримінальному провадженні; 9) особи, до яких застосовані заходи безпеки; 10) особи, які мають відомості про дійсні дані про осіб, до яких застосовані заходи безпеки; 11) експерти (ч. 2 ст. 65 КПК України).
Диспозитивний (відносний, умовний) імунітет наділяє правом свідка відмовитися від дачі показань. Різновидом диспозитивного імунітету $є$ право не свідчити проти себе самого, свого чоловіка (дружини) та інших близьких родичів (п. 3 ч. 1 ст. 66 КПК України). Також диспозитивним імунітетом свідків наділені особи, які мають право дипломатичної недоторканності, а також працівники дипломатичних представництв - без згоди представника дипломатичної установи (ч. 4 ст. 65 КПК України).

Висновок. Отже, на наш погляд, така класифікація імунітету свідків $€$ найбільш повною і точною, оскільки нею охоплюються всі види імунітету свідків.

Таким чином, імунітет свідка - це сукупність правил, які звільняють певні групи свідків від обов'язку давати показання у кримінальному провадженні, а також звільняють від обов'язку свідка свідчити проти себе самого. У зв'язку 3 цим імунітет для свідка підрозділяється на два види імперативний (абсолютний, безумовний) і диспозитивний (відносний, умовний).

Вищевикладене дозволяє зробити висновок про те, що імунітет свідка є важливим інститутом, який забезпечує такі принципи, як презумпція невинуватості та охорона прав і свобод людини і громадянина в кримінальному судочинстві, тому необхідним $є$ усунення проблем, прогалин та вдосконалення чинного законодавства щодо регулювання цього інституту.

\section{REFERENCES}

\section{LIST OF LEGAL DOCUMENTS}

\section{LEGISLATION}

1. Pro drukovani zasoby masovoyi informatsiyi (presu) v Ukrayini [About the print media in Ukraine: Zakon Ukrayiny] vid 16.11.1992 r. № 2782-XII <https://zakon.rada.gov.ua/laws/show/2782-12> data zvernennya 1212.2019 [in Ukrainian].

перспективи 67

1 О Федорова, 'Принцип защиты прав и свобод человека и гражданина в уголовном судопроизводстве'(2006) 12 Закон и право 17. 


\section{BIBLIOGRAPHY}

\section{AUTHORED BOOKS}

2. Ahaev F, Ymmunytety $v$ rossyyskom uholovnom protsesse [Immunity in russian criminal proceed] (dys. ... kand. yuryd. nauk: 12.00.09. M., 1997) 168 [in Russian].

3. Hryhor'ev F, Protsessual'noe polozhenye svydetelya v uholovnom sudoproyzvodstve [Procedural position of the witness] (dys. ... kand. yuryd. nauk. M. 2009) 167 [in Russian].

4. Koryakyn Y, Ymmunytet $v$ uholovnom sudoproyzvodstve [Immunity in criminal proceed] (dys. ... kand. yuryd. nauk:12.00.09. M.,2003) 160 [in Russian].

5. Moskal'kova T, Étyka uholovno-protsessual'noho dokazyvanyya (stadyya predvarytel'noho rassledovanyya) [Ethic in criminal procedural proof (Preliminary review stage)] (Moskva, Spartak 1996) 125 [in Russian].

6. Rudnev V, Ymmunytety $v$ uholovnom sudoproyzvodstve [Immunity in criminal proceed] (dys. ... kand. yuryd. nauk:12.00.09. M.,1997) 193 [in Russian].

7. Smol'kova Y, Protsessual'nyy status svydetelya $v$ rossyyskom uholovnom sudoproyzvodstve [Procedural position of the witness in russian criminal proceed]: ucheb. Posobye (MVD Rossyy, Yrkut VSH MVD SSSR Yrkut·sk, Bratus' tekhtsentr 1997) 40 [in Russian].

8. Stremoukhov A, Pravovaya zashchyta cheloveka [Human rights protection] (SPbHUP 2007) 65 [in Russian].

9. Volkotrub V, Imunitet i problemy yoho zakhystu v kryminal'nomu sudochynstvi [Immunity and problem of it's protection in criminal proceed] (dys. ... kand. yuryd. nauk: 12.00.09. KH., 2002) 192 [in Ukrainian].

10. Ukrayins'kyy tlumachnyy slovnyk [Ukrainian explanatory dictionary] (Tezaurus. 250000 sliv ta slovospoluchen', 2016) 1696 [in Ukrainian].

\section{ARTICLES}

11. Bel'kova O, 'Teoretychni ta praktychni aspekty prava svidka vidmovytysya svidchyty vidnosno sebe, chleniv sim"yi ta blyz'kykh rodychiv'[Theoretical and Practical Aspects of the Right of a Witness to Refuse to Testify in Relation to Myself, Family Members and Close Relatives] (2004) 2 Pidpryyemnytstvo, hospodarstvo i pravo102-105 [in Ukrainian].

12. Endol'tseva A, Endol'tseva U, 'Obespechenye prav y zakonnykh ynteresov svydetelya pry proyzvodstve po uholovnomu delu'[Ensuring the rights and legitimate interests of a witness in criminal proceedings] (2018)4 Vestnyk ékonomycheskoy bezopasnosty 129-134 [in Russian].

13. Fadeev P, 'Problemy formyrovanyya ponyatyy uholovno-protsessual'noho prava y ykh vlyyanye na pravoprymenytel'nuyu praktyku'[Problem of formation the contest in criminal procedural law their impact on law enforcement] (2017) 6 Zakony Rossyy: opyt, analyz, praktyka 104-108 [in Russian].

14. Fedorova O, 'Pryntsyp zashchyty prav y svobod cheloveka y hrazhdanyna $\mathrm{v}$ uholovnom sudoproyzvodstve'[The principle of protection of human and citizen's rights and freedoms in criminal proceedings] (2006) 12 Zakon y pravo 12-18 [in Russian].

15. Mel'nykov $\mathrm{V}$ 'Instytut svidkivs'koho imunitetu $\mathrm{v}$ holovnomu protsesi' [Institute of witnesses immunity in criminal proceed] (2016) 3 Pivnichno-Kavkaz'kyy yurydychnyy visnyk. $<$ https://cyberleninka.ru/article/n/institutsvidetelskogo-immuniteta-v-ugolovnom-protsesse-rossii > data zvernennya 12 hrudnya 2019 roku $>$ [in Russian].

16. Nor V, 'Svidok u kryminal'nomu protsesi Ukrayiny: kolo osib, predmet pokazan ta svidots'kyy imunitet'[Witness in the Criminal Procedure of Ukraine: Circle of Persons, Subject of Testimony and Witness Immunity] Radnyk: Ukrayins'kyy yurydychnyy portal $<$ http://radnuk.info/home/24839—c.html $>$ data zvernennya 12 hrudnya 2019 [in Ukrainian].

17. Obozna O, 'Do pytannya klasyfikatsiyi imunitetiv u kryminal'nomu protsesi Ukrayiny'[On the Question of the Classification of Immunities in the Criminal Process of Ukraine] (2017) 2 Yevropeys'ki perspektyvy [in Ukrainian].

18. Tasakov S, 'Nravstvennoe soderzhanye polozhenyy uholovnoho y uholovno-protsessual'noho zakona o svydetel'skom ymmunytete'[The moral content of the provisions of the criminal and criminal procedure law on witness immunity] (2009) 1 Byznes v zakone 226-228 [in Russian].

19. Tkalya O, 'Klasyfikatsiya pravovykh imunitetiv'[Clasification of legal immunity] (2012) 20 (T.1) Naukovyy visnyk Uzhhorods'koho natsional'noho universytetu 82 [in Ukrainian].

20. Veselov M, Zaremba T, Oleshyts'ka V, 'Instytut imunitetu svidka v kryminal'no-protsesual'nomu pravi'[The Institute of Witness Immunity in Criminal Procedure Law] (2017) 3 Yurydychnyy naukovyy elektronnyy zhurnal 124-128 [in Ukrainian].

21. Volkotrub V, 'Aktual'ni pytannya imunitetu svidkiv v kryminal'nomu sudochynstvi'[Actual question of immunity in criminal proceed] (2003) 3-4 (7-8) Visnyk Khmel'nyts'koho instytutu rehional'noho upravlinnya ta prava: nauk. Chasopy 247-252 [in Ukrainian]. 


\author{
Kharitonova M., \\ Postgraduate student \\ Department of Criminal Procedure \\ Odessa State University of Internal Affairs \\ ORCID ID: 0000-0002-2877-7247
}

DOI: https://doi.org/10.17721/2413-5372.2019.3/239-248

\title{
TESTIMONIAL IMMUNITY AS AN ELEMENT OF THE PRINCIPLE OF PROTECTION OF THE RIGHTS AND FREEDOMS OF MAN AND CITIZEN IN CRIMINAL PROCEEDINGS
}

Annotation. In the conditions of formation of the rule of law, one of the biggest manifestations of the democratization of law enforcement activity in Ukraine is the legislative protection of human rights, the creation of guarantees of the rights and legitimate interests of the individual. In this regard, the legal status of participants in criminal proceedings becomes especially important. In addition, the important task of criminal procedural science is to identify and eliminate gaps in the legal regulation of criminal procedural relations. In this regard, studies are currently being conducted to identify legal issues in the field of law and recommendations are being prepared on this basis.

It is known that every participant of criminal justice has its own legal status, enshrined in the rules of the Criminal Procedure Code of Ukraine. The procedural status of the victim, suspect, accused legislator and procedural scientist are given much attention, including the issues of securing their rights and legitimate interests. The procedural status of a witness in criminal proceedings requires, in our opinion, additional investigation, including through the prism of securing the rights and legitimate interests of the person in conducting pre-trial investigation and judicial proceedings in criminal proceedings. Research into the problems of the theory and practice of witness immunity is relevant, as various aspects of witness immunity are controversial among both theorists and practitioners. Of course, it is, first and foremost, important for witnesses to have additional opportunities for state defense.

The purpose of the article is to address topical issues arising from the reform of criminal procedural legislation, which has created some difficulties in law enforcement practice, including the implementation of the rules governing the institution of immunity of witnesses. In particular, this is explained by contradictory, sometimes unsuccessfully formulated provisions of the legislation itself, which are not always consistent with the implementation of the tasks of judicial reform. In addition, the article raises the problem of witness immunity classification. The authors' different perspectives on the concepts and components of witness immunity are examined. Discussion questions of the classification of the immunity of witnesses are revealed and its classification is divided into categories and categories of testimony provided by witnesses.

The result of the study is to provide valid proposals for improving the legal regulation of the institute of immunity of witnesses in criminal proceedings. Witness immunity is a set of rules that exempt certain groups of witnesses from the obligation to testify in criminal proceedings, as well as exempt a witness from testifying against themselves. In this regard, the immunity of the witness is divided into two types of imperative (absolute, unconditional) and dispositive (relative, conditional).

Key words: immunity for witness; classification of witness immunity; criminal proceedings, witness, immunity of witness, right to defend the scope and subject of testimony; types of immunity.

Стаття надійшла до редакиії журналу 01.11.2019 